\title{
Pelaksanaan asuhan gizi terapi gizi medis (TGM) berpengaruh terhadap lama rawat inap
}

\author{
Nutrition care implementation medical nutrition therapy (MNT) influence to length of stay
}

Ika Yuliati Chasbullah', I Made Alit Gunawan ${ }^{2}$, R. Dwi Budiningsari ${ }^{3}$

\begin{abstract}
Background: Medical Nutrition Therapy (MNT) is one of nutrition care models which focuses on integrated patient management involving active participation of doctors, nutritionists, nurses and other professions within the hospital nutrition care team. One benefit of MNT is the reducing of patients' length of stay (LOS) as an indicator of hospital service quality. Bekasi Municipal Hospital has not implemented integrated nutrition care within a team. The result of monitoring and evaluation during the first quarter of 2006 showed the average of LOS for degenerative diseases patients was 5.97 days.

Objective: To identify the influence of nutrition care implementation by using MNT approach to LOS at Bekasi Municipal Hospital.

Method: The study was quaci-experimental which uses static-group comparison. Samples were patients hospitalized at internal medicine wards of (class) VIP, $1^{\text {st }}, 2^{\text {nd }}$ and $3^{\text {rd }}$ class. Datas were obtained consisted of conventional nutrition care (CNC), MNT, and data of LOS. T-test and Mann Whitney statistical test were used to analyze the influence of types of nutrition care to LOS.

Results: LOS of patients with MNT care was 5.80 days. This was shorter than CNC and statistically significant $(p<0.05)$.

Conclusion: There was a difference between LOS of samples with MNT and CNC. LOS of samples with MNT was shorter than CNC and statistically significant $(p<0.05)$.
\end{abstract}

KEY WORDS conventional nutrition care, medical nutrition therapy, length of stay

\begin{abstract}
ABSTRAK
Latar belakang: Asuhan gizi terapi gizi medis (TGM) merupakan salah satu model asuhan gizi yang menitikberatkan pengelolaan pasien secara menyeluruh dengan keterlibatan aktif dokter, ahli gizi, perawat, dan profesi lain dalam wadah tim asuhan gizi. Salah satu keuntungan TGM adalah menurunkan lama rawat inap yang merupakan salah satu indikator mutu pelayanan rumah sakit. Di Rumah Sakit Umum Daerah (RSUD) Kota Bekasi belum dilaksanakan asuhan gizi secara terpadu dalam satu tim. Hasil monitoring dan evaluasi pada triwulan I 2006 diperoleh hasil rata-rata lama rawat inap pasien penyakit degeneratif 5,97 hari.

Tujuan: Mengetahui pengaruh pelaksanaan asuhan gizi dengan TGM terhadap lama rawat inap di RSUD Kota Bekasi.

Metode: Jenis penelitian ini adalah kuasi eksperimen dengan rancangan static-group comparison. Sampel adalah pasien yang dirawat di bangsal penyakit dalam kelas VIP, 1, 2, dan 3. Data yang dikumpulkan meliputi asuhan gizi secara konvensional, TGM, dan data lama rawat inap. Uji statistik t-test dan Mann Whitney digunakan untuk menganalisis pengaruh jenis asuhan gizi terhadap lama rawat inap.

Hasil: Lama rawat inap pasien dengan asuhan gizi TGM adalah 5,80 hari. Angka tersebut lebih pendek daripada asuhan gizi konvensional dan bermakna secara statistik $(p<0,05)$.

Kesimpulan: Ada perbedaan antara lama rawat inap sampel dengan asuhan gizi TGM dan asuhan gizi konvensional. Lama rawat inap sampel dengan asuhan gizi TGM lebih pendek daripada asuhan gizi konvensional dan bermakna secara statistik $(p<0,05)$.
\end{abstract}

KATA KUNCI: asuhan gizi konvensional, terapi gizi medis, lama rawat inap

\section{PENDAHULUAN}

Penurunan status gizi pada pasien rawat inap, tanpa melihat status gizi pada saat masuk rumah sakit, berhubungan dengan biaya yang lebih tinggi dan lama rawat inap yang lebih panjang (1). Angka lama rawat inap atau length of stay (LOS) merupakan salah satu standar untuk menilai kualitas pelayanan medis yang merupakan indikator dari kinerja suatu rumah sakit. Secara umum LOS yang ideal adalah antara 6-9 hari (2).
Salah satu pendekatan asuhan gizi yang direkomendasikan oleh The American Diabetes Association (ADA) pada 1994 dan Departemen Kesehatan (2003)

\footnotetext{
1. Instalasi Gizi Rumah Sakit Umum Daerah Kota Bekasi, Jl. Pramuka no 55, Bekasi, Jawa Barat

2. Politeknik Kesehatan Kemenkes Yogyakarta Jurusan Gizi, Jl. Tata Bumi No 3, Banyuraden, Gamping, Sleman 55293, Yogyakarta

3. Minat Utama Gizi Kesehatan Fakultas Kedokteran Universitas Gadjah Mada, Jl. Farmako, Sekip Utara, Yogyakarta 55281, email: budiningsari25@yahoo.com
} 
adalah medical nutrition therapy atau terapi gizi medis (TGM). Keuntungan pelaksanaan TGM adalah menurunkan LOS, membantu mempercepat penyembuhan, mencegah timbulnya faktor risiko lanjut, memperbaiki kualitas hidup, dan menghemat biaya (3).

Pada beberapa penelitian yang dilaksanakan di Amerika Serikat dan Kanada, TGM terbukti berhasil digunakan untuk mengelola penyakit degeneratif (3). Di Indonesia, penelitian di 33 rumah sakit (RS) se-Jabotabek menyatakan bahwa kegiatan TGM belum sepenuhnya dilaksanakan, umumnya disebabkan oleh jumlah ahli gizi yang tidak memadai dan kerjasama dengan dokter belum berjalan dengan baik (4). Evaluasi asuhan gizi TGM terhadap outcome seperti lama rawat inap atau LOS belum pernah dilakukan di Indonesia, padahal hasil evaluasi tersebut sangat diperlukan untuk memberi masukan dan motivasi kepada tenaga gizi maupun pihak manajemen rumah sakit dalam upaya peningkatan pelayanan gizi.

Penelitian yang sudah pernah dilaksanakan yaitu penelitian mengenai hubungan antara status gizi awal dengan status pulang dan lama rawat inap pasien dewasa yang dilakukan di 3 (tiga) RS yaitu RS Dr. M. Jamil Padang, RS Dr. Sardjito Yogyakarta, dan RS Sanglah Bali, menemukan bahwa semakin baik status gizi awal saat masuk RS dan asupan energi yang cukup maka akan mempunyai risiko terkecil untuk pulang dalam keadaan tidak sembuh, sedangkan status gizi awal dan asupan energi selama perawatan tidak berpengaruh secara signifikan terhadap lama rawat inap pasien (5). Bagian lain dari penelitian ini yang telah dipublikasikan sebelumnya mengenai pengaruh pelaksanaan TGM terhadap asupan gizi pasien di Rumah Sakit Umum Daerah (RSUD) Kota Bekasi menyatakan bahwa ratarata asupan energi sampel sehari dengan asuhan gizi TGM lebih baik $(86,08 \%)$ dibandingkan sampel dengan asuhan gizi konvensional $(76,52 \%)$ dan hal ini bermakna secara statistik. Demikian pula asupan protein, lemak, dan karbohidrat pada kelompok yang diberi asuhan gizi TGM lebih baik dibandingkan asuhan gizi konvensional (6).

Suatu penelitian yang dilakukan di Eropa tahun 1999 terhadap pelaksanaan asuhan gizi, menemukan lima masalah utama yang umum yaitu: tidak jelasnya masalah tanggung jawab, kurangnya pengetahuan yang diperlukan, kurangnya peran pasien, kerjasama antar tim yang kurang kompak, dan kurangnya peran serta pihak rumah sakit. Untuk menyelesaikan masalah tersebut diperlukan suatu tim pendukung yang diayomi oleh pemerintah dan terdiri dari seluruh staf yang menangani pelayanan dan dukungan gizi termasuk jajaran manajemen rumah sakit (7).

Di RSUD Kota Bekasi, asuhan gizi belum dilaksanakan secara terpadu dalam satu tim. Dalam prosedur tetap pelayanan gizi pasien rawat inap, disebutkan bahwa asuhan gizi dilaksanakan dengan menggunakan pendekatan TGM, namun saat ini belum terjadi koordinasi dan komunikasi yang baik antara dokter, perawat, ahli gizi, dan profesi lainnya. Peran ahli gizi dalam hal ini masih sangat sedikit terutama pada penentuan preskripsi diit. Penentuan diit pasien lebih sering dilakukan oleh dokter tanpa adanya koordinasi dengan ahli gizi, ahli gizi hanya berperan dalam pemberian intervensi yaitu berupa penyediaan makanan dan konseling gizi.

Dari hasil monitoring dan evaluasi pelayanan gizi rawat inap pada semester I tahun 2006 (Januari - Juni) di RSUD Kota Bekasi, diperoleh LOS untuk pasien penyakit dalam adalah 4,88 hari dan pasien penyakit degeneratif adalah 5,97 hari. Walaupun angka tersebut sudah memenuhi LOS ideal (6-9 hari), namun dalam perhitungannya bukan hanya pasien yang pulang dalam keadaan sembuh tetapi termasuk juga pasien pulang paksa atau meninggal sehingga belum dapat menggambarkan efektivitas pelayanan.

Berdasarkan uraian di atas, maka perlu dilakukan penelitian untuk mengetahui pengaruh pelaksanaan asuhan gizi dengan pendekatan TGM terhadap lama rawat inap di RSUD Kota Bekasi.

\section{BAHAN DAN METODE}

Jenis penelitian ini adalah kuasi eksperimen dengan rancangan static-group comparison. Sampel dibagi menjadi 2 (dua) kelompok, kelompok pertama diberikan perlakuan berupa asuhan gizi TGM dan kelompok kedua asuhan gizi konvensional. Populasi dalam penelitian ini adalah semua pasien baru masuk dan dirawat di RSUD Kota Bekasi yang memenuhi kriteria inklusi. Sampel adalah pasien yang dirawat di ruang penyakit dalam kelas VIP, I, II, dan III yang memenuhi kriteria inklusi yaitu: komunikatif, kesadaran compos mentis, menderita penyakit degeneratif tanpa komplikasi dengan tingkat keparahan berdasarkan anamnesis medis, dinyatakan sembuh atau membaik, dan boleh pulang oleh dokter. Kriteria eksklusi adalah pasien yang pulang atas permintaan sendiri atau pulang paksa, pasien meninggal, dan pindah kelas selama observasi.

Besar sampel ditentukan dengan menggunakan rumus pengujian hipotesis untuk dua rata-rata populasi (8) dengan perbedaan lama rawat inap $(\mu 1-\mu 2)^{2}$ pada penelitian ini yaitu sebesar 0,5 hari, tingkat kepercayaan (a) sebesar 1,96 (95\%), kekuatan uji (ß) sebesar 1,28 $(90 \%)$, dan standar deviasi $(\delta)$ sebesar 0,7 (5), maka besar sampel untuk masing-masing kelompok adalah 42. Dengan asumsi $10 \%$ sampel akan hilang selama proses penelitian, besar sampel minimal untuk masing-masing kelompok menjadi 46 , sehingga besar sampel minimal seluruhnya adalah 92 orang. Pemilihan sampel menggunakan cara accidental. Sampel diambil secara berpasangan menurut jenis penyakit (diabetes mellitus atau DM, congestive heart failure atau $\mathrm{CHF}$, stroke non hemoragik atau $\mathrm{SNH}$, hipertensi atau $\mathrm{HT}$, hypertension heart disease atau HHD) dan kelas perawatan (kelas I dan VIP serta kelas 2 dan 3). 
Instrumen yang digunakan adalah formulir kegiatan TGM, data identitas, dan karakteristik sampel.

Variabel penelitian terdiri dari variabel bebas yaitu jenis asuhan gizi TGM dan konvensional, variabel terikat adalah lama rawat inap. Asuhan gizi TGM adalah proses kegiatan pelayanan gizi kepada pasien selama dirawat meliputi: pengkajian status gizi, penentuan masalah dan tujuan terapi gizi, penentuan preskripsi diit, intervensi berupa penyediaan makanan dan konseling gizi serta monitoring dan evaluasi. Kegiatan dilaksanakan oleh tim asuhan gizi yang terdiri dari dokter, perawat, ahli gizi, dan profesi lain dengan komunikasi dan koordinasi yang baik pada saat visite bersama dan pertemuan mingguan. Hasil kegiatan tertulis pada formulir TGM yang disertakan pada dokumen rekam medik pasien. Sedangkan asuhan gizi konvensional adalah proses kegiatan pelayanan gizi kepada pasien selama dirawat, yang biasanya hanya fokus pada penyediaan makanan dan konseling gizi, sedangkan perencanaan diit oleh ahli gizi hanya dilakukan untuk kasus tertentu, penentuan diit lebih sering dilakukan oleh dokter. Monitoring dan evaluasi gizi tidak selalu dilakukan. Koordinasi dengan profesi lain sangat kurang, visite bersama dan pertemuan mingguan tidak dilakukan. Hasil kegiatan konseling gizi tidak ditulis pada formulir khusus, hanya ditulis pada lembar instruksi rekam medik pasien. Lama rawat inap adalah lamanya sampel dirawat di rumah sakit dalam hari yang dihitung sejak hari pertama masuk sampai pasien pulang dinyatakan sembuh atau membaik oleh dokter. Kegiatan asuhan gizi, baik TGM maupun konvensional dilakukan oleh enumerator, yaitu ahli gizi masing-masing ruang rawat yang telah mendapat latihan penyegaran. Enumerator adalah ahli gizi rumah sakit dengan pendidikan D3.

Analisis univariat dilakukan untuk menggambarkan karakteristik sampel, uji chi square digunakan untuk menguji homogenitas sampel. Analisis bivariat dilakukan untuk melihat adanya pengaruh asuhan gizi TGM terhadap lama rawat inap, untuk variabel dengan sebaran data normal menggunakan t-test dan Mann Whitney untuk variabel dengan sebaran data tidak normal. Penelitian ini telah mendapatkan persetujuan dari Komite Etik Penelitian Kedokteran dan Kesehatan Fakultas Kedokteran Universitas Gadjah Mada.

\section{HASIL}

Menurut data semester pertama tahun 2006, ratarata lama rawat inap (LOS) di RSUD Kota Bekasi untuk penyakit degeneratif adalah selama 5,97 hari. Berdasarkan jenis penyakit yaitu: DM selama 7,78 hari, CHF selama 5,29 hari, SNH selama 7,61 hari, HT selama 5,09 hari, dan HHD selama 4,08 hari.

Tabel 1. Karakteristik sampel penelitian

\begin{tabular}{|c|c|c|c|c|c|c|c|c|}
\hline \multirow{3}{*}{ Karakteristik } & \multicolumn{4}{|c|}{ Jenis asuhan gizi } & \multirow{2}{*}{\multicolumn{2}{|c|}{ Total }} & \multirow{3}{*}{$\mathbf{x}^{2}$} & \multirow{3}{*}{$\mathbf{p}$} \\
\hline & \multicolumn{2}{|c|}{ Konvensional } & \multicolumn{2}{|c|}{ TGM } & & & & \\
\hline & $n$ & $\%$ & $n$ & $\%$ & $n$ & $\%$ & & \\
\hline \multicolumn{9}{|l|}{ Jenis kelamin } \\
\hline Laki-laki & 18 & 39,13 & 20 & 43,48 & 38 & 41,30 & \multirow{3}{*}{0,045} & \multirow{3}{*}{0,832} \\
\hline Perempuan & 28 & 60,87 & 26 & 56,52 & 54 & 58,70 & & \\
\hline Jumlah & 46 & 100 & 46 & 100 & 92 & 100 & & \\
\hline \multicolumn{9}{|l|}{ Tingkat pendidikan } \\
\hline Rendah & 25 & 54,35 & 29 & 63,04 & 54 & 58,70 & \multirow{4}{*}{0,767} & \multirow{4}{*}{0,682} \\
\hline Menengah & 19 & 41,30 & 15 & 32,61 & 34 & 36,96 & & \\
\hline Tinggi & 2 & 4,35 & 2 & 4,35 & 4 & 4,34 & & \\
\hline Jumlah & 46 & 100 & 46 & 100 & 92 & 100 & & \\
\hline \multicolumn{9}{|l|}{ Pekerjaan } \\
\hline PNS & 15 & 32,61 & 13 & 28,26 & 28 & 30,43 & \multirow{4}{*}{1,034} & \multirow{4}{*}{0,596} \\
\hline Swasta & 31 & 67,39 & 32 & 69,57 & 63 & 68,48 & & \\
\hline Pelajar & 0 & 0 & 1 & 2,17 & 1 & 1,09 & & \\
\hline Jumlah & 46 & 100 & 46 & 100 & 92 & 100 & & \\
\hline \multicolumn{9}{|l|}{ Umur (tahun) } \\
\hline$\leq 40$ & 5 & 10,87 & 4 & 8,70 & 9 & 9,78 & \multirow{4}{*}{0,155} & \multirow{4}{*}{0,926} \\
\hline $41-60$ & 30 & 65,22 & 30 & 65,22 & 60 & 65,22 & & \\
\hline$\geq 61$ & 11 & 23,91 & 12 & 26,08 & 23 & 25,00 & & \\
\hline Jumlah & 46 & 100 & 46 & 100 & 92 & 100 & & \\
\hline \multicolumn{9}{|l|}{ Status gizi awal (IMT) } \\
\hline Kurus & 2 & 4,35 & 1 & 2,18 & 3 & 3,26 & \multirow{4}{*}{2,053} & \multirow{4}{*}{0,358} \\
\hline Normal & 31 & 67,39 & 37 & 80,43 & 68 & 73,91 & & \\
\hline Gemuk & 13 & 28,26 & 8 & 17,39 & 21 & 22,83 & & \\
\hline Jumlah & 46 & 100 & 46 & 100 & 92 & 100 & & \\
\hline
\end{tabular}

Keterangan: TGM = terapi gizi medis

PNS = pegawai negeri sipil

IMT = indeks massa tubuh

$\mathrm{n}=$ jumlah sampel 
Jumlah sampel penelitian sebanyak 92 orang yang dibagi menjadi dua kelompok masing-masing 46 orang untuk asuhan gizi TGM dan 46 orang untuk asuhan gizi konvensional. Penentuan jumlah sampel dilakukan secara proporsional untuk masing-masing kelas perawatan. Jenis kelamin sampel penelitian terbanyak adalah perempuan, baik yang diberi asuhan gizi konvensional maupun TGM masing-masing sebesar $60,87 \%$ dan $56,52 \%$. Sebagian besar pendidikan sampel baik yang diberi asuhan gizi konvensional maupun TGM adalah rendah ( $\leq$ Sekolah Dasar) masing-masing sebesar $54,35 \%$ dan $63,04 \%$. Sebagian besar sampel bekerja di sektor swasta masingmasing sebesar $67,39 \%$ pada kelompok konvensional dan $69,57 \%$ pada kelompok TGM. Umur sampel terbanyak 4160 tahun, yaitu masing-masing sebesar $65,22 \%$ pada kedua kelompok. Sebagian besar status gizi awal berdasarkan indeks massa tubuh (IMT) tergolong normal yaitu sebesar $67,39 \%$ sampel dengan konvensional dan sebesar $80,43 \%$ sampel dengan TGM. Hasil uji chi square menunjukkan tidak terdapat perbedaan proporsi karakteristik sampel baik dari jenis kelamin, tingkat pendidikan, pekerjaan, umur maupun status gizi awal (IMT) (Tabel 1).

Pengambilan data terhadap lama rawat inap dilakukan setelah sampel dinyatakan boleh pulang oleh dokter, dihitung sejak sampel baru datang sampai boleh pulang dengan cara tanggal keluar dikurangi tanggal saat sampel masuk rumah sakit. Hasil analisis dapat dilihat pada Tabel 2.

Tabel 2. Hasil analisis rata-rata lama rawat inap berdasarkan jenis asuhan gizi

\begin{tabular}{lccc}
\hline \multirow{2}{*}{ Variabel } & \multicolumn{2}{c}{ Jenis asuhan gizi } & \multirow{2}{*}{$\mathbf{p}$} \\
\cline { 2 - 3 } & Konvensional & TGM & \\
\hline $\begin{array}{l}\text { Rata-rata } \\
\text { lama rawat inap }\end{array}$ & $7,54 \pm 3,79$ & $5,80 \pm 2,49$ & 0,023 \\
\hline
\end{tabular}

Keterangan: $\mathrm{TGM}=$ terapi gizi medis

Rata-rata lama rawat inap sampel secara keseluruhan yang diberi asuhan gizi TGM ternyata lebih pendek $(5,80 \pm$

Tabel 3. Rata-rata lama rawat inap berdasarkan jenis penyakit dan asuhan gizi

\begin{tabular}{cccc}
\hline \multirow{2}{*}{$\begin{array}{c}\text { Jenis } \\
\text { penyakit }\end{array}$} & \multicolumn{2}{c}{ Jenis asuhan gizi } & \multirow{2}{*}{$\mathbf{~}$} \\
\cline { 2 - 3 } & Monvensional & TGM & \\
\cline { 2 - 3 } & Mean \pm SD & Mean \pm SD & \\
\hline DM & $8,53 \pm 3,8$ & $5,92 \pm 2,88$ & 0,005 \\
CHF & $6,25 \pm 1,98$ & $5,75 \pm 2,31$ & 0,650 \\
SNH & $7,28 \pm 5,37$ & $6,57 \pm 1,27$ & 0,366 \\
HT & 4,33 & 4,33 & $* *$ \\
HHD & 5,50 & 4,00 & $* *$ \\
\hline
\end{tabular}

Keterangan: ${ }^{* *} \quad=$ tidak dapat diuji statistik karena sampel terlalu kecil

TGM = terapi gizi medis

$\mathrm{DM}=$ diabetes mellitus

$\mathrm{CHF}=$ congestive heart failure

$\mathrm{SNH}=$ stroke non hemoragik

$\mathrm{HT}=$ hipertensi

$\mathrm{HHD}=$ hypertension heart disease
2,49 hari) dibandingkan dengan sampel yang diberi asuhan gizi konvensional $(7,54 \pm 3,79$ hari) $(p<0,05)$.

Menurut kategori jenis penyakit, rata-rata lama rawat inap sampel dengan asuhan gizi konvensional lebih panjang dibandingkan sampel dengan asuhan gizi TGM pada semua kategori jenis penyakit, tetapi setelah dilakukan uji statistik hanya rata-rata rawat inap penyakit DM yang bermakna $(p<0,05)$ (Tabel 3$)$.

Analisis lama rawat inap berdasarkan kelas perawatan menunjukkan sampel dengan asuhan gizi konvensional pada tiap kategori kelas perawatan memiliki rata-rata lama rawat inap lebih panjang dibandingkan sampel dengan asuhan gizi TGM, setelah dilakukan uji statistik ternyata hanya sampel kelas 1 dan VIP yang menunjukkan hasil bermakna $(p<0,05)($ Tabel 4$)$.

Tabel 4. Rata-rata lama rawat inap berdasarkan kelas perawatan dan jenis asuhan gizi

\begin{tabular}{lccc}
\hline \multirow{3}{*}{ Kelas perawatan } & \multicolumn{2}{c}{ Jenis asuhan gizi } & \multirow{2}{*}{$\mathbf{p}$} \\
\cline { 2 - 3 } & Konvensional & TGM & \\
\cline { 2 - 3 } & Mean \pm SD & Mean \pm SD & \\
\hline Kelas 1 dan VIP & $6,89 \pm 3,10$ & $4,84 \pm 1,70$ & 0,021 \\
Kelas 2 dan 3 & $8,00 \pm 4,20$ & $6,48 \pm 2,75$ & 0,308 \\
\hline
\end{tabular}

Keterangan: $\mathrm{TGM}=$ terapi gizi medis

\section{BAHASAN}

Hasil analisis terhadap lama rawat inap menunjukkan bahwa rata-rata lama rawat inap seluruh sampel dengan asuhan gizi TGM lebih pendek dibandingkan dengan asuhan gizi konvensional, masing-masing adalah selama $5,80 \pm 2,48$ hari (TGM) dan 7,54 $\pm 3,79$ hari (konvensional). Setelah dilakukan analisis secara statistik perbedaan tersebut bermakna $(p<0,05)$, hal ini membuktikan bahwa salah satu keuntungan dari pelaksanaan TGM adalah menurunkan LOS.

Rata-rata lama rawat inap sampel dengan asuhan gizi TGM $(5,80$ hari) termasuk ideal (6-9 hari), tetapi relatif tidak berbeda dengan lama rawat inap penyakit degeneratif RSUD Kota Bekasi (5,97 hari). Hal ini disebabkan perhitungan LOS pada penelitian ini hanya dilakukan terhadap pasien yang pulang dalam keadaan sembuh atau membaik, sedangkan perhitungan LOS RSUD Kota Bekasi dilakukan terhadap seluruh pasien, baik pulang dalam keadaan sembuh atau pulang paksa atau meninggal, padahal pasien yang keluar meninggal atau pulang paksa dalam keadaan belum sembuh tidak menggambarkan keadaan yang sebenarnya (2).

Rata-rata LOS penyakit DM dengan asuhan gizi konvensional selama 8,53 $\pm 3,8$ hari sedangkan asuhan gizi TGM selama 5,92 $\pm 2,88$ hari. Analisis statistik menunjukkan hasil bermakna $(p<0,05)$, artinya asuhan gizi TGM mempengaruhi lama rawat inap sampel dengan penyakit DM. Angka LOS asuhan gizi TGM tersebut juga 
lebih kecil daripada LOS pada pasien DM di RSUD Kota Bekasi ( 7,78 hari).

Sejalan dengan penelitian ini, penelitian tentang lama rawat inap pada pasien DM menunjukkan bahwa lama rawat inap pasien yang diberi pengetahuan mengenai pengobatan dasar oleh suatu tim penanganan diabetes yang terdiri dari dokter, perawat, dan ahli gizi dapat menurunkan lama rawat dari 11 hari menjadi 8 hari (9).

Untuk penyakit lain sebenarnya rata-rata lama rawat inap dengan asuhan gizi TGM pada penelitian ini lebih pendek daripada di RSUD Kota Bekasi, seperti CHF selama 5,75 hari, SNH selama 6,57 hari, HT selama 4,33 hari, dan HHD selama 4,00 hari, sedangkan lama rawat inap di RSUD Kota Bekasi masing-masing selama 5,29 hari untuk CHF, selama 7,61 hari untuk $\mathrm{SNH}$, selama 5,09 hari untuk HT, dan selama 4,08 hari untuk HHD. Hal ini menunjukkan bahwa asuhan gizi TGM tidak berpengaruh pada perbedaan lama rawat inap.

Penelitian tentang lama rawat inap pada pasien dewasa yang dilakukan di RS Dr. M. Jamil Padang, RS. Dr. Sardjito Yogyakarta, dan RS Sanglah Bali mendukung hal tersebut, bahwa jenis penyakit berpengaruh secara signifikan terhadap lama rawat inap (5). Selain itu hasil penelitian mengenai LOS yang dilakukan di Denmark, penyakit CHF mendapatkan hasil bahwa keparahan penyakit merupakan variabel yang berhubungan dengan LOS lanjut usia dengan CHF (10). Dengan demikian dapat dikatakan bahwa lama rawat inap berbeda pada setiap jenis penyakit dan tergantung pula pada tingkat keparahan penyakit tersebut.

Rata-rata LOS berdasarkan kelas perawatan menunjukkan pada sampel dengan asuhan gizi TGM, LOS lebih pendek dari pada konvensional, namun setelah dilakukan uji statistik hasil yang bermakna hanya pada perbedaan LOS sampel kelas 1 dan VIP sedangkan untuk kelas 2 dan 3 tidak bermakna. Hasil penelitian yang dilakukan di RS Dr. M. Jamil Padang, RS. Dr. Sardjito Yogyakarta, dan RS Sanglah Bali tentang lama rawat inap mendukung hasil penelitian ini, bahwa kelas perawatan berpengaruh terhadap lama rawat inap, pasien kelas 2 dan 3 mempunyai risiko 3,4 kali lebih besar untuk dirawat lebih lama dibanding kelas 1 (5).

Perbedaan lama rawat inap pada sampel dengan asuhan gizi konvensional dan TGM disebabkan pengelolaan pasien rawat inap dengan TGM dilakukan secara menyeluruh dengan memperhatikan setiap perubahan pada pasien secara individual. Pengelolaan pasien dilakukan oleh tim asuhan gizi yang setiap anggotanya berperan aktif memberikan informasi mengenai evaluasi terhadap kondisi pasien dari beberapa disiplin ilmu seperti medis, perawatan, gizi, dan farmasi yang dilakukan pada visite bersama setiap hari dan pada pertemuan mingguan di ruang rawat masing-masing. Penelitian di Denmark mendapatkan hasil bahwa prospek perbaikan pelayanan gizi akan meningkat jika manajemen RS menetapkannya sebagai prioritas utama. Pelayanan gizi juga akan meningkat jika masing-masing profesi mempunyai waktu yang cukup, dan di tingkat penyelenggara makanan jika monitor dan evaluasi dijalankan terhadap alur makanan keseluruhan dari dapur ke pasien. Sedangkan pada tingkat pasien, jika akses dialog dengan petugas ruang rawat baik dan pasien dapat menerima informasi mengenai pilihan makanan dan minuman (11). Demikian pula bagian dari penelitian ini yang telah dipublikasikan sebelumnya, membuktikan bahwa rata-rata asupan zat gizi yang terdiri dari energi, protein, lemak, dan karbohidrat pada kelompok yang diberi asuhan gizi TGM lebih baik secara signifikan dibandingkan asuhan gizi konvensional (6). Asupan gizi yang lebih baik mempercepat proses penyembuhan penyakit dan menurunkan komplikasi sehingga memperpendek lama rawat inap di rumah sakit (12).

Pernyataan yang mendukung hasil penelitian ini adalah manfaat tim asuhan gizi yaitu mempertahankan status gizi, mencegah atau mengurangi timbulnya komplikasi, dan yang paling penting adalah biaya perawatan menjadi lebih rendah akibat masa rawat inap yang lebih pendek. Hal yang perlu diperhatikan dalam pelaksanaan asuhan gizi adalah peran aktif dan kerjasama dari masing-masing anggota, hal ini dapat dikatakan menjadi syarat utama suksesnya misi tim asuhan gizi. Pada pelaksanaan asuhan gizi diperlukan pengetahuan dan keahlian khusus dalam bidang gizi, karena proses pemberian diit pada pasien, penilaian status gizi, menyusun rencana dan menentukan diit yang akan diberikan, mencatat kemampuan toleransi dan komplikasi yang timbul serta menentukan bila diit harus diakhiri atau dialihkan dalam bentuk lain merupakan proses yang kompleks sehingga diperlukan pelatihan secara terus menerus (5).

\section{KESIMPULAN dan SARAN}

Berdasarkan hasil analisis yang telah dilakukan dalam penelitian ini, maka dapat diambil kesimpulan bahwa rata-rata lama rawat inap sampel dengan asuhan gizi TGM secara keseluruhan lebih pendek dibandingkan dengan sampel yang mendapat asuhan gizi konvensional dan bermakna secara statistik. Berdasarkan kategori jenis penyakit dan kelas perawatan, hanya lama rawat sampel dengan penyakit DM dan sampel pada kelas 1 dan VIP yang menunjukkan hasil bermakna.

Saran yang dapat diberikan adalah asuhan gizi dengan pendekatan TGM perlu dilaksanakan di RSUD Kota Bekasi sebagai upaya meningkatkan mutu pelayanan gizi khususnya pelayanan pasien rawat inap. Agar dapat dilakukan secara optimal, sebaiknya dilakukan perbaikan untuk mengatasi beberapa kekurangan yang ditemui pada pelaksanaan TGM, antara lain: pada komponen sistem asuhan gizi, secara keseluruhan perlu dilakukan re-organisasi tim asuhan gizi; pada komponen sumber 
daya, perlu peningkatan mutu sumber daya manusia (SDM) dengan cara mengadakan kursus penyegar asuhan gizi TGM; pada komponen proses, perlu ditingkatkan kerja sama antar anggota tim untuk mengusahakan agar LOS pasien kelas 2 dan 3 lebih baik. Pertemuan secara berkala dapat digunakan sebagai sarana komunikasi, misalnya dengan membahas kasus suatu penyakit.

Dengan mempertimbangkan terbatasnya jumlah SDM (ahli gizi) yang ada saat ini, sebagai langkah awal kegiatan TGM diprioritaskan untuk pasien pada kelas perawatan 1 dan VIP dan untuk pasien yang memerlukan diit khusus pada perawatan kelas 2 dan 3 .

Untuk penelitian selanjutnya disarankan dilakukan penelitian terhadap pelaksanaan TGM pada penyakit lain dengan menganalisis faktor-faktor lain yang mempengaruhi asupan gizi dan lama rawat inap seperti kualitas menu, jenis terapi, dan tingkat keparahan penyakit.

\section{UCAPAN TERIMA KASIH}

Penulis mengucapkan terima kasih kepada Direktur RSUD Kota Bekasi atas izin yang telah diberikan untuk melakukan penelitian di RSUD Kota Bekasi, kepada para enumerator serta semua pihak atas segala dukungan dan bantuan yang telah diberikan sejak persiapan sampai dengan pengumpulan data. Ucapan terima kasih juga disampaikan kepada seluruh pasien yang telah bersedia menjadi sampel pada penelitian ini.

\section{RUJUKAN}

1. Braunchweig C, Gomez S, Sheean P. Impact of declines in nutritional status on outcomes in adult patients hospitalized for more than 7 days. J Am Diet Assoc 2000; 100: 1316-24.

2. WHO-Depkes. Panduan, teori dan tehnik perencanaan rumah sakit. Jakarta: WHO-Depkes; 1997.

3. Indrarti M. Terapi gizi medis sebagai model dalam asuhan gizi. Naskah lengkap Short Course Asuhan
Gizi Rumah Sakit Program Studi IKM FK-UGM; 2005 Maret 31-April 2; Yogyakarta, Indonesia.

4. Waspadji S. Diitetik dan pelayanan medis: tantangan dan wacana mutakhir dalam menghadapi era globalisasi. Prosiding Konas Persagi; 2002; Jakarta, Indonesia.

5. Syamsiatun $\mathrm{NH}$, Hadi $\mathrm{H}$, Juffrie $\mathrm{M}$. Hubungan antara status gizi awal dengan status pulang dan lama rawat inap pasien dewasa di rumah sakit. Jurnal Gizi Klinik Indonesia 2004; 1(1): 27-33.

6. Chasbullah IY, Gunawan IMA, Budiningsari RD. Pelaksanaan asuhan gizi dengan pendekatan terapi gizi medis (TGM) berpengaruh terhadap asupan gizi pasien di RSUD Kota Bekasi. Jurnal Gizi Klinik Indonesia 2008; 5(1): 1-8.

7. Beck AM, Balkn UN, Furst $P$, Hasunen $K$, Jones $L$, Keller U, Melchior JC, Mikkelsen BE, Schauder P, Sivonen L, Zinck O, Oien H, Ovesen L. Food and nutrition care in hospital: how to prevent undernutririon - report and guidelines from the Council of Europe. Clin Nutr 2001; 20(5): 455-60.

8. Lemeshow S, Hosmer Jr DW, Klar J. Adequacy of sample size in health studies. Pramono D.1997 (Alih bahasa). Yogyakarta: Gadjah Mada University Press; 1997.

9. Cavan D, Hamilton P, Everett J, Kerr D. Reducing hospital inpatient length of stay for patients with diabetes. Diabet Med 2001; 18(2): 162-4.

10. Lassen KO, Kruse F, Bjerrum M, Jensen L, Hermansen K. Nutritional care of Danish medical inpatiens: effect on diitary intake and the occupational groups perspectives of intervention. Nutrition Journal 2004; 3:12.

11. Lassen KO, Olsen J, Griderslev E, Kruse F, Bjerrum $M$. Nutritional care of medical inpatienst: a health technology assessment. BMC Health Services Research 2006; 6:7.

12. Wyszynski D, Crivelli A, Esquerro $S$, Rodrigues $A$. Assesment of nutritional status in a population of recently hospitalized patients. Mediciana (B Aires) 1998; 58(1): 51-7. 